This item was submitted to Loughborough's Research Repository by the author.

Items in Figshare are protected by copyright, with all rights reserved, unless otherwise indicated.

\title{
Developing sustainable arrangements for "proactive" disaster risk financing in Java, Indonesia
}

\section{PLEASE CITE THE PUBLISHED VERSION}

https://doi.org/10.1108/IJDRBE-01-2020-0006

\section{PUBLISHER}

Emerald Publishing Limited

\section{VERSION}

VoR (Version of Record)

\section{PUBLISHER STATEMENT}

This article is published under the Creative Commons Attribution (CC BY 4.0) licence. Anyone may reproduce, distribute, translate and create derivative works of this article (for both commercial and non-commercial purposes), subject to full attribution to the original publication and authors. The full terms of this licence may be seen at http://creativecommons.org/licences/by/4.0/legalcode.

\section{LICENCE}

CC BY 4.0

\section{REPOSITORY RECORD}

Soetanto, Robby, Ferry Hermawan, Alistair Milne, Jati Utomo Dwi Hatmoko, Sholihin As'ad, and Chusu He. 2020. "Developing Sustainable Arrangements for "proactive" Disaster Risk Financing in Java, Indonesia". Loughborough University. https://hdl.handle.net/2134/12014820.v1. 


\section{Developing sustainable arrangements for "proactive" disaster risk financing in Java, Indonesia}

\section{Robby Soetanto}

Department of Civil and Building Engineering, Loughborough University, Loughborough, UK

Ferry Hermawan

Department of Civil Engineering, Faculty of Engineering, Diponegoro University, Semarang, Indonesia

\author{
Alistair Milne \\ Loughborough, UK \\ Jati Utomo Dwi Hatmoko
}

Department of Business and Economics, Loughborough University,

Department of Civil Engineering, Faculty of Engineering, Diponegoro University, Semarang, Indonesia

Sholihin As'ad

Department of Civil Engineering, Universitas Sebelas Maret Fakultas Teknik, Surakarta, Indonesia, and

Chusu He

Department of Accounting, Finance and Economics, Coventry University - London Campus, London, UK
Developing sustainable arrangements

Received 24 January 2020 Revised 28 January 2020 Accepted 28 January 2020

\begin{abstract}
Purpose - Recent years saw a paradigm shift from ex post (reactive) to ex ante (proactive) approaches (e.g. insurance) to disaster risk financing for building resilience of communities in developing countries. To facilitate adoption, the approaches should be adapted so that they can be technically feasible and culturally desirable to the local context. This paper aims to report an exploratory study to elaborate the existing arrangements to deal with the impacts of disaster and the potential to shift to a more proactive disaster risk financing in Indonesia.
\end{abstract}

Design/methodology/approach - A series of stakeholder engagement activities in Semarang and Solo, Indonesia was conducted to ascertain the existing arrangements for disaster risk financing at local

(C) Robby Soetanto, Ferry Hermawan, Alistair Milne, Jati Utomo Dwi Hatmoko, Sholihin As'ad and Chusu He. Published by Emerald Publishing Limited. This article is published under the Creative Commons Attribution (CC BY 4.0) licence. Anyone may reproduce, distribute, translate and create derivative works of this article (for both commercial and non-commercial purposes), subject to full attribution to the original publication and authors. The full terms of this licence may be seen at http:// creativecommons.org/licences/by/4.0/legalcode

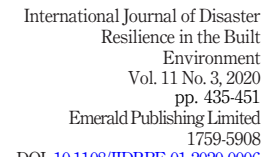
DOI 10.1108/IJDRBE-01-2020-0006 
IJDRBE 11,3

government level, the challenges/barriers to the adoption of insurance, education and policies to facilitate the transformation from reactive to proactive process. Thematic analysis was applied to transcribed conversations during interviews, focus groups and workshops. Identification of emerging issues/themes was also guided by the researchers' notes during the events, and facilitated by qualitative analysis software, Atlas Ti®. This was complemented by an analysis of regulations and documents provided by the local stakeholders.

Findings - The local governments heavily rely on contingency fund, which is not enough and often significantly delayed to fund recovery and reconstruction of public infrastructure. The use of insurance is limited in both public and private sectors, particularly in the majority of low-income communities. Various barriers and challenges were identified under several categories, namely, institutional, cultural, affordability, lack of awareness and knowledge, insurance arrangement process and lack of trust. The findings also suggest that improving insurance education should involve multiple stakeholders, and both formal and informal routes should be pursued.

Originality/value - The research fills the gap of knowledge in disaster risk financing in the context of developing countries, specifically in local governments and communities in Indonesia. The findings may be replicable for other developing countries with low adoption of ex ante financial instruments for dealing with the impacts of disaster.

Keywords Community, Insurance, Flooding, Developing countries, Disaster risk financing, Financial instruments

Paper type Research paper

\section{Introduction}

Because of its geographical location, socio-economic vulnerabilities and other cultural and political factors, Indonesia is one of the countries most prone to disasters. Disasters have impacted much of the population; most severely affecting those vulnerable communities with low income who have very little resources to recover in the aftermath of disaster events. Notwithstanding non-economic impacts, such as physical and mental health and loss of life, physical damages to infrastructure (such as transportation, telecommunication and public housing) disrupt businesses and raise socio-economic problems in the impacted community.

The financial costs of recovery and reconstruction are significant. The World Bank (2012) indicates that, in Indonesia, the annual economic impact of disaster is estimated at 0.3 per cent of Gross Domestic Product (GDP), and the cost of a major disaster (i.e. from an earthquake) could potentially exceed 3 per cent of GDP (about US\$30bn). More recently, the Indonesian Minister of Finance highlighted the need to adopt a new disaster risk financing and insurance strategy to better cope with the impact of disasters, protect public assets and accelerate recovery, rather than relying on the state budget, particularly an annual contingency fund of IDR3.1tn (only around US $\$ 240 \mathrm{~m}$ or 0.03 per cent of GDP) from 2005 to 2017. This is insufficient to deal with disasters (Strait Times, 2018).

Further, international donor fund is often insufficient for emergency relief, let alone recovery and reconstruction of public infrastructure. Donor funds are often concentrated for the most high profile disasters with extensive media coverage. Proactive ex ante financial planning will allow faster, more reliable and cheaper response in the event of disaster (DfID, 2017). This should also prevent disasters off-setting development gains, and encourage enhanced resilience improvement measures. This initiative has provided a strong impetus for rethinking on alternative protection mechanisms for recovering from disaster damages and losses in low- and middle-income countries.

At individual level, the take-up of micro insurance for property protection in developing countries in Asia (including Indonesia) is generally low (Surminski et al., 2019). Property recovery and reconstruction often rely on other financing mechanisms, which could be from 
the central/local government or foreign aids. Mochizuki et al. (2019) argue that there is a marked distinction between financing emergency events and recovery and reconstruction processes. Emergency situation forces coordination of aid to reach the needed communities more swiftly and effectively. But this is often not the case with reconstruction process. In several case studies, Mochizuki et al. (2019) found that post-disaster recovery and reconstruction process has been slow, because of governance complexity and mismatch between financing mechanism and socio-economic, cultural and institutional context. Here, access to available funding by agencies is often less critical than the process of deploying financial aid to ultimately reach the victims. As a consequence, the impacted population are often in the temporary shelters for many years, or have to live in unfit accommodation.

This paper presents a review of the arrangements for managing the financial costs of disasters in Central Java, Indonesia, exploring the potential of shifting to more proactive disaster risk financing based on ex ante financial instruments (i.e. insurance) rather than ex post calls on inevitably limited contingency reserves. It reviews existing arrangements and reports on a series of local stakeholder engagements to explore the socio-economic, cultural and political factors that often prevent wider adoption of financial instruments. Unless these factors are identified, understood and taken into account in developing policies and designing financial instrument products, implementation is unsound and likely to fail. These issues were explored as part of an investigation of financial planning for disasters with a particular focus on flooding risk in Central Java (FloodFinJava project, sponsored by UK Global Challenge Research Fund).

The key research questions addressed include:

$R Q 1$. What are the existing financial arrangements for disaster financing?

RQ2. What are the challenges/barriers to the adoption of financial instruments (e.g. insurance)?

RQ3. If education is key to wider adoption, what are the required activities and challenges, and who should be responsible for these activities?

RQ4. What policies should be implemented to facilitate the transformation from reactive (ex post arrangements) to proactive (ex ante arrangements) process?

The stakeholder engagement process for exploring these research questions included focus group discussions and workshops with stakeholders of disaster risk financing in Semarang and Solo (both in Central Java, Indonesia).

The following sections describe the FloodFinJava project, detailed engagement process and method, existing disaster risk financing arrangements, key stakeholders and budgeting for disaster fund, before a discussion of the key findings. Conclusions are drawn with a view to present key factors that enable or prevent more proactive disaster financing, and to inform the development of policies that facilitate improvements to the existing arrangements.

\section{FloodFinJava project}

The FloodFinJava research project was established with the goal of developing tools for risk communication to assist stakeholders such as local officials, community representatives and business leaders, to understand the potential financial risks of flooding and the potential for using insurance and other risk transfer instruments to manage their financial impacts. The work on the project has identified two main challenges that need to be overcome for effective development of disaster financing and use of risk transfer instruments: 
IJDRBE 11,3

\section{8}

(1) Unavailability of data: Existing tool, such as InaSAFE [www.inasafe.org, see Pranantyo et al. (2015) for application example] provides a helpful framework, but it is just a simulation tool, there are substantial data gaps and it does not cover financial losses.

(2) Institutional issues: There is a need for institutional development of both private sector insurance and improved public sector risk transfer programmes to deal with the financial consequences of disaster.

The major challenge is gradual institutional development. The perspective explored in FloodFinJava is that - when insurance arrangements are undeveloped - then to support the necessary institutional development, it may not be necessary to devote a large amount of resources to developing sophisticated models of flooding or other natural hazards, paralleling those used to manage catastrophe risk in developed countries. A lot can be done with very simple modelling. This is likely to be necessary because of sparse data. It is still though worthwhile to undertake some simple modelling because this supports the first necessary steps to improve on what are currently very limited institutional arrangements for disaster risk financing.

The potential for insurance-based risk transfer can be explored with very simple initial calculations of expected losses and some allowance for risk and insurance margins. This can encourage increased "ex ante" awareness of the risks of natural hazard, hence stimulating the demand for private insurance and at the same time help with private insurance supply. It can also help government agencies to better incorporate risks of natural hazard into their financial planning, so that in the event of a major disaster, materialising funds are more easily made available for response and recovery. With increased private insurance and more sophisticated disaster risk finance planning in the public sector, there will be increased demand for better data and more sophisticated modelling and for training in disaster risk finance. A "virtuous" circle may be achievable, with over time increased awareness of risks, better data, improved modelling and more sophisticated mechanisms for risk transfer within public and private sector, all of which is mutually reinforcing.

Thus, this paper argues that knowledge of sophisticated catastrophe modelling as deployed in much more mature insurance market in most developed countries would not be sufficient to address the lack of adoption on risk transfer/financial instruments. Instead, cultural and socio-economic issues are often more dominant barriers to wider adoption. Only through better understanding, appreciation of these issues and education, wider adoption could be promoted alongside the availability of data and modelling tools. This paper discusses cultural and socio-economic issues which were identified via stakeholder engagement activities, explained in the following section.

\section{Stakeholder engagement}

A series of stakeholder engagement activities was undertaken in the form of interviews, focus group discussions and workshops in March 2018, July 2018, September 2018 and July 2019. The objectives were to identify and elaborate:

- existing arrangements for disaster risk financing;

- governance of disaster management and related policies/regulations;

- challenges and barriers with the existing arrangements and the potential for the adoption of insurance; and

- issues in relation to enhancing insurance take-up via education. 
These approaches of engagement were deemed appropriate for the exploratory nature of the research. The key local stakeholders included Regional Disaster Management Agency (Badan Penanggulangan Bencana Daerah [BPBD]) both at city and provincial level, Regional Planning and Development Agency (Badan Perencanaan dan Pembangunan Daerah [BAPPEDA]), Department of Public Work (Departemen Pekerjaan Umum [PU]) and River Authority (Balai Besar Wilayah Sungai [BBWS] Bengawan Solo). These types of stakeholder were present in Semarang and Solo, apart from the River Authority whose duty was specific for Solo. At national level, the FloodFinJava team engaged Maipark Reinsurance, Financial Service Authority (Otoritas Jasa Keuangan [OJK]), Ministry of Finance, as well as an insurance consultant and academic who specialised in actuarial science. Timing, engagement events and stakeholder roles are listed in Table I.

Thematic analysis was applied to transcribed conversations during interviews, focus groups and workshops. Identification of emerging issues/themes was also guided by the researchers' notes during the events. These notes provided a means to reflect on what was said, with details and clarification provided by the more accurate transcriptions. Atlas Ti $\mathbb{R}$ version 8 was chosen as the software tool to undertake this analysis because of its ability to handle different sources of qualitative data. Analysis of regulations and documents provided by the local stakeholders was incorporated to enrich the findings.

\section{Current arrangements for disaster risk financing}

The existing arrangements for disaster risk financing are described under several sections as follows.

\subsection{Legal and institutional framework}

Following the major impact of the December 2004 tsunami on Aceh province, Indonesia has developed a comprehensive legal framework to improve disaster risk management. This was set out in Disaster Management Law (Law number 24/2007). This law established a national Badan Nasional Penanggulangan Bencana (BNPB) and a local disaster management agency (BPBD) and stipulated the roles and responsibilities of these agencies. BNPB and BPBD are responsible for the organisation of disaster mitigation prior, during and after disaster events. The law also sets out the right and responsibilities of members of the public and communities and international humanitarian agencies.

\begin{tabular}{|c|c|c|c|}
\hline Timing & Engagement event & Stakeholder role & \\
\hline March 2018 & Meeting with Maipark Reinsurance & Major re-insurance company & \\
\hline \multirow[t]{2}{*}{ July 2018} & $\begin{array}{l}\text { Meeting with insurance consultant } \\
\text { Workshop in Solo }\end{array}$ & $\begin{array}{l}\text { Consultant } \\
\text { BPBD, BBWS (River Authority) and } \\
\text { PU }\end{array}$ & \\
\hline & Meeting in Semarang & $\mathrm{BPBD}$ & \\
\hline Sept 2018 & $\begin{array}{l}\text { Stakeholder meeting in Semarang } \\
\text { Meeting with Maipark Reinsurance }\end{array}$ & $\begin{array}{l}\text { BPBD and BAPPEDA Semarang } \\
\text { Major re-insurance company }\end{array}$ & \\
\hline \multirow[t]{4}{*}{ July 2019} & Workshop in Semarang & $\begin{array}{l}\text { Local government, users and } \\
\text { communities }\end{array}$ & \\
\hline & Workshop in Solo & $\begin{array}{l}\text { Local government, PU and } \\
\text { communities }\end{array}$ & Table I. \\
\hline & Seminar in OJK & $\begin{array}{l}\text { Finance service authority, Ministry of } \\
\text { Finance and academic/consultant }\end{array}$ & $\begin{array}{l}\text { Stakeholder } \\
\text { engagement }\end{array}$ \\
\hline & Meeting with Maipark Reinsurance & Major re-insurance company & activities \\
\hline
\end{tabular}


IJDRBE

11,3

440

A key part of this framework is the mechanisms for allocation of emergency funds for response and recovery from disasters. BNPB and BPBD manage their own emergency funds allocated to them in the annual rounds of national and regional government budgeting. The scale of disaster events (such as the number of victims and area impacted) determines the level of government to response (national, provincial or city/regency) and the size of emergency funds.

The agencies are also responsible for developing guidance for reconstructing damaged infrastructures, allocating emergency funds, collecting and managing humanitarian funds from public and national and international agencies. Although preparation prior to disaster is an integral part of the process, it is often perceived as low priority and under-resourced. Figure 1 presents a hierarchy of authority for the allocation of funding for disaster financing. Regulations were proposed by the President, and approved and enacted via parliamentary process. The regulations establish national disaster reserve fund, provincial disaster fund and city/regency disaster funds. An occurrence of disaster would trigger the release of the fund. Depending on the magnitude/level of disaster, the disaster management

Figure 1.

Hierarchy of authority for the allocation of funding for disaster financing

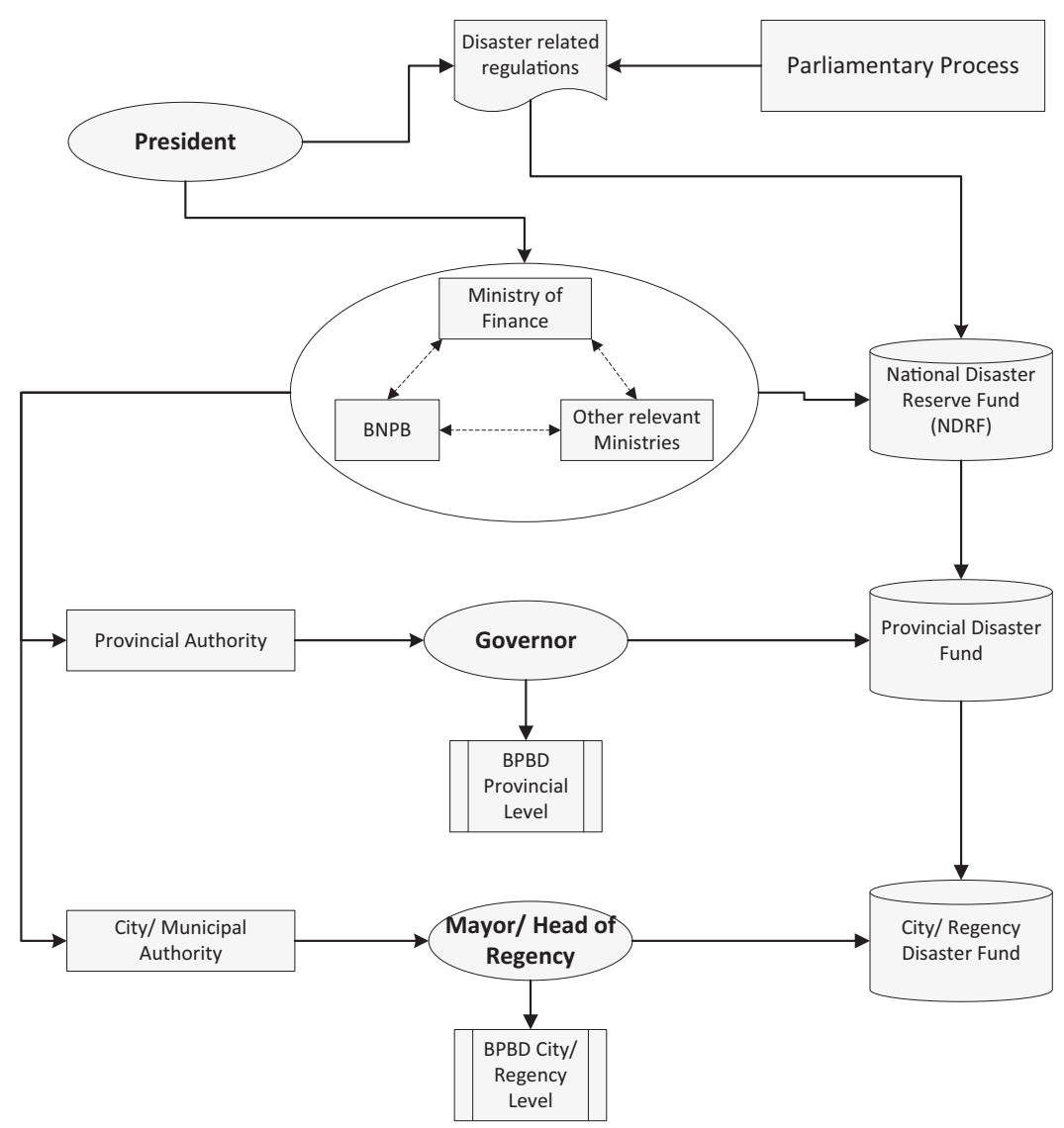

Source: Stakeholder engagement, supported/confirmed by World Bank (2012) 
agencies on consultation with executive post-holders (i.e. governor or mayor/head of regency) would release the fund. At national level, Ministry of Finance, BNPB and other relevant ministries (including Social and Public Work) would coordinate actions, led by the President. If alternative (ex ante) disaster risk financing strategy (e.g. insurance and catastrophe bond) is adopted, the stakeholders would include finance institutions such as OJK, Badan Kebijakan Fiskal/Fiscal Policy Agency and Bapepam (Capital Market Financial Institution Supervisory Agency) as regulators, and insurance companies specialised in disasters, such as Maipark Reinsurance (mostly at national level) and Jasindo (at local level).

\section{Developing sustainable arrangements}

\subsection{Financial arrangements for disaster responses}

Government Regulation 2008 stipulates mechanism for distribution of emergency funds through BNPB at national level, and BPBD at provincial and residence/city levels. The amount of emergency fund being deployed depends on the scale of disaster. Larger fund should be deployed following a declaration of national disaster by the central government. This declaration is made as an outcome of consultation in the local and central government. This explains the reason why representatives from BPBD and BAPPEDA in Semarang (in focus group discussion in September 2018) did not seem to be much concerned about largescale flooding events where local resources were inadequate for response and recovery. Their view was that if Semarang did not have resources to cope, then funds would come from BPBD Central Java, and if BPBD Central Java did not have sufficient resources then funds would come from BNPB.

The stakeholders seemed to be reasonably content with this provision of emergency fund. They did not consider that insurance might be of help to provide funding for recovery. General insurance against extreme flooding or other disasters is a discussion that only makes sense at national level in Jakarta in the context of their overall fiscal planning. However, they did acknowledge one key gap in the arrangements for disaster financing. The legislation leaves very little scope for discretion. Funds are only available to help households, normally for restoring housing and replacement of essential possessions. Following a disaster, an opportunity to claim funds for a certain area is announced. Then all households in that area, regardless of circumstances, can make a claim for financial compensation. The maximum amount of claim was IDR $15 \mathrm{~m}$ per household, which was not considered sufficient to recover the properties to the pre-disaster state, let alone to improve their resilience. This is on an indemnity basis with some processes for checking that claims are accurate.

What has been left out is any mechanism for protection of government-owned assets schools, hospitals and government offices. If these are damaged by floods, then any repair has to come out of the regular annual budget for the local area. The workshop participants suggest that there is often misalignment between seasonal timing of the floods (when they usually occur during rainy season between November and February) and the release of reconstruction fund for public infrastructures. The costs of repairs should be reported in the middle of the year, and the reconstruction fund is released the following year. Without immediate actions, the facility condition may get worse, rendering the facilities unusable with possibility beyond or more expensive repairs.

Semarang City Government has insured public buildings (including government offices, hospitals and local health clinics, schools and market buildings), based on "book value" which is much less than "market value" of the insured buildings. A typical insurance premium is 1.25 per cent of book value, with the exception of market buildings where it is between 14 and 25 per cent of book value. The use of "book value" is to reduce the total amount of insurance premium. The total premium for all buildings was compiled and then 
IJDRBE 11,3

\section{2}

auctioned to any insurance companies with credible track record, ability to cover the potential claims and having an office in Semarang. Under this arrangement, insurance payout will not cover repair cost directly, but will go to regional account (i.e. Kas Daerah in Bahasa Indonesia). Although this arrangement may help alleviate the burden for reconstruction, it would neither be able to fully cover the repair costs, nor be timely to allow fully functional buildings, following disasters. Nevertheless, this attempt to insure public buildings should be seen as an incremental development towards good practice as promoted by Finance Minister Sri Mulyani Indrawati, who urged the government to start insuring public buildings from 2019 (Strait Times, 2018). Other public infrastructures, including roads and bridges, are not insured.

\subsection{Budgeting for disaster fund}

Reformation movement in the late 1990s has brought a decentralisation initiative of functions and authorities from central to local governments. Despite some progresses, issues related to bureaucracy and approval remains a challenge. One of these is budgeting of disaster fund at local government. Fahlevi et al. (2019) discovered that the local budget allocation for disaster management was not proportionate to disaster risk, but it was found to correlate with the total annual budget of the local government. Further, they found that the allocated disaster budget in BPBD in the Aceh province, northern Indonesia, is relatively small compared to the local government budget (on average less than 1 per cent). These findings seem to be consistent with our findings in Semarang (Table II and Figure 2). Over the past eight years, the proportion of disaster budget to overall budget is between 0.072 and 0.147 per cent, which is far less than 1 per cent. In terms of the amount, disaster budget shows a similar trend to the overall budget, with two exceptions in the year 2014 and 2016. The overall budget shows an increasing trend but the disaster budget does not. Apart from year 2014 and 2016, year 2017 and 2018 do not fit the increasing trend. Further scrutiny of the breakdown of the budget indicates that there was large expenditure to deal with large floods in 2014 and 2016, requiring the city government to reallocate the funding. This suggests a reactive approach to disaster risk financing.

\section{Barriers and challenges for enhancing disaster risk financing}

Although the law is silent on the possible use of financial instruments, it seems possible for provincial governments to purchase insurance to protect state assets under several regulations, including Government Regulation No 45/2013 (Article 111), Government Regulation No. 27/2014 (Article 45) and The Ministry of Home Affairs Regional Financial Management Guidelines No. 13/2006 (Article 52) (World Bank Group, 2018).

\begin{tabular}{lcccc}
\cline { 2 - 5 } & Year & City government budget (IDR) & Disaster budget (IDR) & Proportion (\%) \\
\cline { 2 - 5 } & 2011 & $2,200,000,000,000$ & $1,588,537,700$ & 0.072 \\
Table II. & 2012 & $3,100,000,000,000$ & $2,597,232,800$ & 0.084 \\
Annual regional & 2013 & $3,100,000,000,000$ & $3,828,656,400$ & 0.124 \\
budget and disaster & 2014 & $3,700,000,000,000$ & $5,436,022,000$ & 0.147 \\
budget of Semarang & 2016 & $4,300,000,000,000$ & $4,600,989,000$ & 0.107 \\
City Government & 2017 & $4,400,000,000,000$ & $5,158,560,000$ & 0.117 \\
& 2018 & $4,700,000,000,000$ & $4,030,630,700$ & 0.086 \\
\hline
\end{tabular}


Given a predominantly top-down approach to the implementation of disaster management, this represents a significant structural problem in the disaster management system, in which BNPB suggested amending Law 24/2007 to rectify the problem (World Bank Group, 2018). World Bank Group (2018) further recommended local governments to obtain adequate insurance cover for assets and fiscal liabilities and develop supporting mechanisms (including processes and rules) and relevant data.

Our stakeholder engagements in Solo and Semarang suggest several issues that need to be taken into account for disaster planning and disaster risk financing in the public sector, and in exploring the use of insurance and other risk transfer instruments. Those are presented and discussed as follows.

\subsection{Institutional challenge}

Stakeholder responses suggest that institutions rely on emergency funds from central government and regency/city government. Currently, they do not use financial instruments. Local authorities emphasise emergency response (i.e. there is little preparedness), and mainly adopt a reactive approach. There is no fund to recover from infrastructure damages, as emergency funds are used to help human victims.

At the time of stakeholder engagement, there were discussions on how to allocate funding for emergency responses to purchasing insurance cover, by public sector at national and regional levels. It seems that these initiatives to more proactive approaches are still very centralised, relying on decisions by the Ministry of Finance. The local government relies on a mandate from the central government, enacted within regulation, to implement insurance schemes:

We will adhere to any regulation; if it stipulates an insurance, then we will adhere [...]. It should start from the Minister of Finance, and then go down to Mayor [. . . ].

There are further issues in relation to multi-institution collaboration, because the ownership of infrastructural assets rests on different institutions. It was acknowledged that dealing with disaster impact is a multi-institutional affair, prior, during and after the event. For example, the Ministry of Education is responsible for schools, but the Ministry of Public Work should also be involved in the recovery as it has a department which is responsible for public building's operation and maintenance. Here, the improvement of infrastructure (in terms of increasing resilience to hazards) does not solely rely on the responsible party (i.e. the Ministry of Education). In Semarang workshop in July 2019, it was found that a school's headmaster did not know that his school was covered by insurance arranged by the city
SEMARANG CITY GOVERNMENT BUDGET 2011-2018

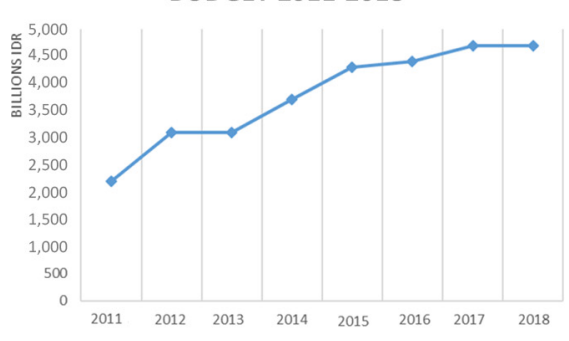

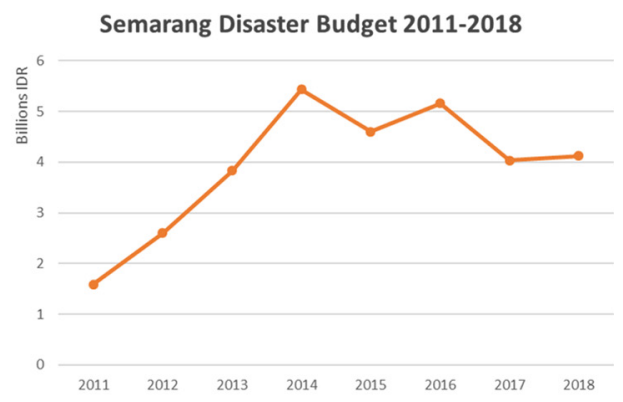

Figure 2.

Profile of Semarang City Government budget and disaster budget (2011-2018)
Developing sustainable arrangements

443

Source: BAPPEDA 
IJDRBE 11,3

government. This suggests a lack of communication to the users, which can lead to lack of ownership to deal with the impacts of flooding, hence deflecting the responsibility to those at higher hierarchy in the government. Multi-institution challenges are not uncommon in the disaster recovery and reconstruction effort, such as those found in the development of budget governance for disaster risk reduction (with particular focus on flooding) in Nepal (Mercy Corps, 2019). Although these institutions can potentially be engaged in the development of financial instruments, the interface, interaction and responsibility between relevant institutions could be an issue in selecting and determining parameters of financial instruments. Despite an exemplar shown by the Semarang City Government to cover public property damages using insurance, the level of take-up in other regions is generally expected to be very low without a clear mandate and regulation from the central government. This claim was further strengthened by inflexible management practice (the tendency to implement regulations rigidly), lack of political will (and imagination in problem solving) and low level of available financing.

The concept of insurance (and the purchase of other protection schemes) is also not aligned with the legitimation of the use of public funding. It is essential to demonstrate accountability by providing evidence of physical (tangible) outputs/products for all public money spent within government budgeting cycle. This perception discourages the adoption of innovative risk transfer/financial instruments in the public sector.

\subsection{Cultural issues}

In the past decade, the severity and frequency of flooding have been reduced because of government initiatives to implement structural and non-structural measures in Semarang and Solo. Recent years have not seen major flooding events like those in the 1990s, although there is no certainty that those would not happen again. However, "nuisance" flooding is still very common phenomenon in the communities. One school's headmaster said:

[They] were not disasters, not flooding [. . .] only [water] inundation when it rains for about one or two hours $[\ldots]$ then no problem. If it rains more than three hours, area around my school will certainly be inundated.

The main cause of this flooding is generally poorly designed and maintained drainage. Because of its high frequency, the communities develop their resilience (i.e. capabilities) to deal with the impacts. The stakeholders consulted in this study suggested that flooding impact was often seen much less than that of earthquakes and fires, although its high frequency of occurrence is still a concern. All these combined may help to explain low insurance take-up in the communities. Cultural issues feature strongly in the discussion, one public official expressed that:

[Insurance] culture still does not exist in the public [...].

The concept of insurance is not a familiar one in Javanese culture, which believes God's will, and which discourages individuals to think in advance about perils and their potential impacts. Some principles may also be in conflict with religious belief. At community level, recovery from damages often relies on community self-help (i.e. "gotong royong" in Bahasa Indonesia). One community leader stated:

Thus, if there are damages due to flooding [...]. Whether it is levee, or house, recovery is through gotong royong to amend the damages in the area. For larger damages we report to village office.

This suggests that community cohesion and connection-to-place shape community perception on flooding, and their response and recovery from flood events. Previous 
research in communities in Jakarta also found that members of community were well adapted to flooding, and some made their living from their connection with neighbourhood in flood-vulnerable areas (Hellman, 2015). Hellman (2015) further questioned top-down policy of relocation from the view of flooded communities, who perceived relocation as a more threatening issue than flooding. Instead, Rahmayati et al. (2017) proposed designs for temporary shelters and facilities through community-led design processes that meet the needs of communities without disconnecting them from their neighbourhood.

\subsection{Affordability of insurance}

There was a high degree of agreement that affordability, coupled with perception of flood risk influences the take-up of insurance for majority of community members. In Semarang, BAPPEDA in 2012, via a major international insurance company, offered flood insurance schemes to high-risk communities. However, the level of premium for the communities in the areas of high flood risk is prohibitive. The same flood insurance was also offered to low-risk communities; the level of premium was affordable, but the communities simply did not think that it was necessary to cover themselves against flooding as it had never happened before.

The take-up of insurance by private sectors (i.e. commercial and industries) and individuals is largely by the wealthy/middle class, particularly in the Greater Jakarta area. Insurance is still little used by the majority of public, particularly those in smaller cities and rural areas, such as our cases in Semarang and Solo. This reflects both lack of demand and lack of supply of insurance products outside Greater Jakarta, where there is much greater availably of data for assessing hazard risks and much greater experience of insuring a wide range of properties.

Insurance on buildings owned by state-owned enterprises (i.e. the Badan Usaha Milik Negara) is quite common. For public buildings owned by local governments, it is safe to say that it is a discretionary of the local governments to insure their public buildings. We found that the Semarang City Government had insured public buildings, but found no evidence in Solo. However, the insurance cover was not sufficient to bring the properties into their initial condition because of limited budget, as one official commented:

We do not have a culture for insuring [...]. We need budget, although limited budget. Thus, we need to prioritise which areas to spend our budget.

The Semarang City Government also stated that there was no insurance (and hence, compensation) to the impacted public and community (such as in cases of accidents because of fallen trees). In such cases, it is still unclear which department is responsible for and the extent and scope for compensation.

\subsection{Lack of awareness and knowledge}

The concept of insurance does not seem to be easy to internalise for individuals (de Bock and Gelade, 2012). Lack of awareness and knowledge of insurance was found to be one consensus among participants of the workshops. Some who understand the basic concept of insurance would prefer putting their money in savings than paying insurance premium, because they would be able to keep the money with some interest. Some even perceived that they would get the premium back if they did not claim anything during that year. One participant commented that:

Not enough knowledge by the public, so there lacks interest [in insurance].

Participants mentioned that there was a need for the government and insurance industry to actively promote the adoption of insurance: 
IJDRBE 11,3

Government has a role to play in socialising insurance to the public, and also the insurance industry is really needed.

Several participants highlighted the important roles that leaders of local neighbourhood and community play in dissemination of information for raising awareness and knowledge. One participant underlined the effective role of women who were members of Family Welfare Education (Pendidikan Kesejahteraan Keluarga [PKK]) group in the local community, for socialising insurance adoption:

Women [housewives] can instigate faster communication [...] faster than "thunder" [...] if housewives get together, information can spread quickly.

\subsection{Process of arranging insurance}

Participants argued that to facilitate wider adoption, the process of arranging insurance should be made easier. A participant referred to the overly bureaucratic process of life insurance arranged in their work with involvement of department head. Lack of understanding of the process could hamper adoption, as a participant commented:

It is very important that inexperience community members are given guidance.

However, it is critical that knowledge and skills are developed so that they can arrange it by themselves.

Arranging insurance should be easy so that the leaders do not have to arrange it for their community members.

This suggests the need for wider dissemination of insurance knowledge and skills to all members of community to build confidence and independence in assessing their insurance need and arranging it by themselves.

\subsection{Lack of trust}

The discussion with participants reached a consensus that general level of trust was positively correlated with insurance adoption. Patt et al. (2009) c.f. de Bock and Gelade (2012) suggested three levels of trust in relation to insurance adoption: the trust in the product itself, the trust in the institution involved and the degree of interpersonal trust of the individuals. The discussion with participants reflects on the last two comments:

Insurance providers should have credibility and capacity to cover the risks of customers.

We still doubt with insurance; whether it honours its promise. Insurance staff always change. For example, I meet X, who in 3 months, left. When I wish to claim, I communicate with $Z$, who must be convinced. Thus, we do not trust because staff change and is inconsistent. When we wish to claim, the person has gone.

A similar finding was found by Tower and McGuinness (2011) in Kenya. They argued that lack of trust in insurance companies tends to relate to negative experiences and lack of understanding of how insurance works. The negative experiences are likely to be passed on via social networks, spreading distrust of insurance companies.

\section{Enhancing insurance adoption via education}

Education emerged as an important theme throughout our stakeholder engagement, highlighting the lack of awareness and knowledge for a wider adoption of insurance (and 
other financial instruments). Insurance was perceived as a new approach to deal with remedying the impacts of disaster. Some participants felt that the concept is against the accepted norms and belief, and they had not fully appreciated different financial products that could be developed to meet one's needs and circumstances. This phenomenon is fairly common in developing countries such as those in Asia, which may have incompatible cultural issues to the concept of insurance. This is supported by Surminski et al. (2019) who found generally low insurance penetration rate in Asia.

Promoting the adoption of insurance through education for the public is regarded as one of the first steps to increase the demand for the ecosystem of proactive disaster risk financing. Tower and McGuinness (2011) adopted theory of behaviour change in finance to promote wider adoption of insurance via radio campaign to reach low-income population in Kenya. The theory proposes that individual must be aware of the availability of insurance, acquire the knowledge to understand the insurance concepts, possess the skills to engage with insurance process and have a positive attitude towards adoption of insurance. They are represented in a series of processes with a goal for individuals to adopt insurance, as depicted in Figure 3.

Using this process as a framework for discussion, participants were asked to identify and discuss:

- required actions to facilitate the process;

- roles of individuals and/or organisations who are responsible for the actions; and

- the challenges, for each phase of the process. Key themes for these are presented in Table III.

In awareness-raising phase, socialisation of insurance concept was perceived as a predominant action. It is followed by the need to change mindset, raise personal care of individuals, improve understanding of insurance for community leaders and testimony of those who have adopted insurance. The challenges at this phase were (lack of) trust, higher cost, the need for cost benefit analysis, lack of understanding and culture and the need to follow-up understanding with real actions. It is worth noting that the absence of logical prediction of disaster/flood risk was identified as one challenge, which highlights the need for a simple tool (such as that proposed in FloodFinJava) that can help community to make informed decision on insurance. The participants considered that government, insurance staff and institutions where they work should have roles to play in promoting the awareness of insurance. Community/young leaders were pointed out to be a focal point for promotion by setting an example.

In knowledge acquisition phase, socialisation, again, was a predominant theme. Participants also suggested the involvement of social science and economic teachers in giving guidance and workshop to the community, and collaboration between institutions (public and private) and community for socialisation. The challenges were lack of resource to socialise insurance to wider communities, heavy workload of teachers, lack of time and interest, raising demand for insurance and different level of knowledge in the community.

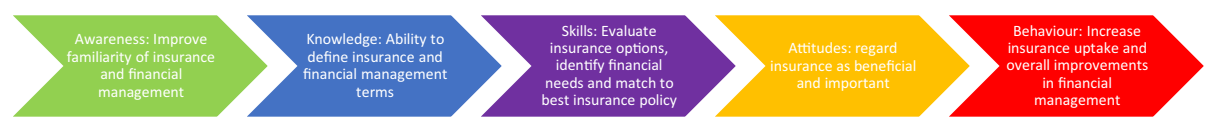

Source: Tower and McGuinness (2011)

Figure 3.

Process of behaviour change for insurance adoption 


\section{IJDRBE 11,3}

Knowledge

Skills

Table III.

Key themes of required actions, challenges and responsibilities/roles for behaviour change process

\begin{tabular}{|c|c|c|c|}
\hline Phase & Action & Challenge & Responsibility/role \\
\hline
\end{tabular}

Awareness Socialisation, change Lack of trust, higher cost, need mindset, personal care, for cost benefit analysis, lack understanding of insurance of understanding and culture, (community leaders) and provide testimonies

Socialisation, involve social science and economic teachers, guidance and workshop for community and collaboration between institutions and community for socialisation

Disciplined and trusted management to convince public, training, involve social science teachers, provide information of insurance products and education for individuals that can plan their future Attitude Instruction from local government leader, provide evidence of benefits and family education follow understanding with real actions and logical prediction of disaster/flood risk

Wider socialisation to communities, heavy workload of teachers, lack of time and interest, raise demand for insurance and different level of knowledge in the community

Insurance training for wider

Government, institutions, community leaders, insurance staff and young leaders

Staff of insurance company, insurance sector and community, insurance company, insurance role model, teachers and community leaders and members who have adopted insurance Insurance sector, insurance companies, role models, trained teachers and individuals who have adopted insurance

Need national regulation to back-up local government leaders and insurance sector needs to maintain trust
Community leaders in collaboration with local politicians and leaders and older people as role model

The responsibilities were perceived to rest on insurance companies, community leaders as role model, teachers and community members who have adopted insurance.

It is interesting to note that disciplined and trusted management emerged as one of the actions in skills development phase. This suggests that participants place trusted management highly, before development of skills. Providing training and information of insurance product clearly, involving social science teachers and general education for individuals that can plan their future were identified as the actions to develop skills. Again, limited resource for undertaking insurance training for the wider public was identified as a challenge, as well as lack of early education for insurance awareness and quality of human resource. Similar responsibilities to knowledge acquisition phase were proposed for this phase.

In attitude development phase, participants considered instruction from local government leader, providing evidence of benefits and family education as the necessary actions. Participants identified the need for national regulations to back-up local government leaders, and insurance sector to maintain trust as the challenges. The need for collaboration between community leaders with local politicians and leaders was identified as part of responsibility for undertaking actions in the development phase. Again, participants considered role models as important in facilitating behaviour change process, but this time, the role models are older people, as opposed to younger role models in awareness-raising phase. 


\section{Conclusions}

It is now widely accepted that effective management of the financial impact of disasters requires a "proactive" approach, using insurance and other financial arrangements to establish before disaster takes place how the financial costs of recovery will be met. There are large potential benefits of staking such an approach in Indonesia with its relatively high exposure to risks of flooding, tropical storms, earthquakes, tsunamis and other disasters and limited government resources for responding to disaster.

This study has explored the existing arrangements to deal with the impacts of disaster and the potential to shift to a more proactive disaster risk financing, via a series of stakeholder engagement activities in two cities in Central Java, Indonesia, i.e. Semarang and Solo.

The findings confirm that the local governments rely on contingency funds, which are insufficient to meet post-disaster costs of recovery and reconstruction of public infrastructure and are often significantly delayed. In the public sector, the use of ex ante financial instruments (i.e. insurance) is limited to public buildings, and there is a lack of evidence on consistent adoption across local governments. Although the use of financial instruments is not detailed in existing law, it seems possible for local governments to purchase insurance to protect state assets under several regulations (World Bank Group, 2018). However, wider adoption seems remote. For the private sector, the use of insurance is perhaps more necessity and has been adopted to a reasonable degree, particularly for those major companies and wealthy individuals. However, majority of individuals at community level, never use insurance.

Varieties of responses were given on the actions, challenges and responsibilities for insurance education, suggesting lack of consensus on the channels/institutions who have main responsibility for education. The findings suggest that improving insurance education should involve multiple stakeholders, and both formal and informal routes should be pursued. Formal routes include developing policies/regulations to promote/support use of insurance in public and private sectors, allocating more resources for socialisation, developing school curricula and providing teacher education. Informal routes include role model and testimony from local/community leaders, champions and celebrities and promotion via PKK group to reach community at grass root level.

Various barriers and challenges were identified under several categories, namely, institutional, cultural, affordability, lack of awareness and knowledge, insurance arrangement process and lack of trust. These barriers and challenges seem to be interrelated, and may be overcome by a combined top-down and bottom-up approaches for developing sustainable arrangements for "proactive" disaster risk financing across national, provincial and city/residence levels. Government may instigate a systemic radical shift from reactive to proactive disaster risk financing, by implementing supportive policies, mechanism (including processes and rules) and relevant data, having strong political will and identifying champions across all levels.

\section{Acknowledgement}

The authors wish to acknowledge the funding provided by UK Natural Environment Research Council (NERC), Department for International Development (DFID) and Economic and Social Research Council (ESRC) via Global Challenge Research Fund (GCRF) (Grant Ref: NE/R014361/1). The authors wish to thank Dr Nur Miladan, Rintis Hadiani, Dr Kusumaningdyah Nurul Handayani and Agus P Saido who supported stakeholder workshops and focus group discussions; research assistants at Universitas Diponegoro (UnDip, Semarang) and Universitas Sebelas Maret (UNS, Solo) who helped in the data 


\section{IJDRBE 11,3}

collection and transcription; and participants of the workshops, focus groups discussion and interviews.

\section{References}

de Bock, O. and Gelade, W. (2012), "The demand for microinsurance: a literature review", Research Paper No. 26, International Labour Office, Geneva.

DfID (2017), “Centre for global disaster protection”, Department of International Development (DfID) in the news, DfID Media Team.

Fahlevi, H., Indriani, M. and Oktari, R.S. (2019), "Is the Indonesian disaster response budget correlated with disaster risk?”, Jàmbá: Journal of Disaster Risk Studies, Vol. 11 No. 1, p. 759, available at: https://doi.org/10.4102/jamba.v11i1.759

Hellman, J. (2015), "Living with floods and coping with vulnerability", Disaster Prevention and Management: An International Journal, Vol. 24 No. 4, pp. 468-483.

Mercy Corps (2019), "Budget governance for disaster risk reduction and climate change adaptation under Nepal's new federal system", Policy briefing, Zurich Flood Resilience Alliance, Mercy Corps, November.

Mochizuki, J. Hallwright, J. and Handmer, J. (2019), "Enabling factors for financing and implementing postdisaster operations", ADB Economic Working Paper Series, No. 594.

Patt, A., Peterson, N., Carter, M., Velez, M., Hess, U. and Suarez, P. (2009), "Making index insurance attractive to farmers", Mitigation and Adaptation Strategies for Global Change, Vol. 14, pp. 737-753.

Pranantyo, I.R., Fadmastuti, M. and Chandra, F. (2015), "In a SAFE applications in disaster preparedness", AIP Conference Proceedings, Vol. 1658, p. 060001, doi: 10.1063/1.4915053.

Rahmayati, Y., Parnell, M. and Himmayani, V. (2017), "Understanding community-led resilience: the Jakarta floods experience", Australian Journal of Emergency Management, Vol. 32 No. 4, pp. 58-66.

Strait Times (2018), "Indonesia adopts new financing and insurance strategy to tackle disasters", 10 October.

Surminski, S., Panda, A. and Lambert, P.J. (2019), "Disaster insurance in developing Asia: an analysis of market-based schemes", ADB Economic Working Paper Series, No. 590.

Tower, C. and McGuinness, E. (2011), "A friend indeed': evaluation of an insurance education radio campaign in Kenya", Partner organizations: Microfinance Opportunities and Association of Kenya Insurers, funded by the International Labor Organization.

World Bank (2012), Indonesia: Advancing a National Disaster Risk Financing Strategy - Options for Consideration, The World Bank, Washington, DC.

World Bank Group (2018), Developing Parametric Insurance for Weather Related Risks for Indonesia, The World Bank, Washington, DC.

\section{About the authors}

Robby Soetanto teaches Construction Management at Loughborough University, UK. His current research focuses on urban flood risk management in developing countries. Previously, he was Lloyds TSB Insurance Post-doctoral Research Fellow, investigating remediation of flood-damaged domestic properties. As principal investigator or co-investigator, his research has been funded by governments (Engineering and Physical Science Research Council, NERC, European Union, Higher Education Academy, British Council, United Kingdom Research and Innovation) and private companies (Lloyds TSB and Hewlett Packard). He was a World Class Professor at Institut Teknologi Sepuluh Nopember, Indonesia, and a Visiting Professor at Ryerson University, Canada. He led the award-winning BIMHub initiative (http://bim-hub.lboro.ac.uk/) and received Premier Award of the Chartered Institute of Building's International Innovation and Research Awards 2014 (http://iandrawards.ciob.org/node/ 69). Robby Soetanto is the corresponding author and can be contacted at: R.Soetanto@lboro.ac.uk 
Ferry Hermawan is a Lecturer of Civil Engineering at Diponegoro University, Indonesia. In the past 15 years, his research focuses on strategic management of public building in the local authority context. He holds $\mathrm{PhD}$ from Coventry University, UK. He has been the Head of Construction Management Laboratory since 2016. He is a Co-Investigator in: Blue-Green Infrastructure in Semarang (BuGIS) project, Newton Fund - Institutional Link - KLN/INSINAS (2017-2019) funded by the British Council and Ristekdikti, and Financial planning for natural disasters: the case of flooding risk in Central Java (FloodFinJava) project (2018-2020) funded by NERC, DFID and ESRC.

Alistair Milne is a Professor of Financial Economics at the School of Business and Economics, Loughborough University, UK. He has worked at Cass Business School, the Bank of England, the University of Surrey, London Business School, HM Treasury and for the Government of Malawi. His principal research interests are: financial infrastructures and financial technology; financial risk management; bank regulation and capital management; and banks and credit in the macroeconomy. He is the author of "The Fall of the House of Credit", a detailed account of the global financial crisis. He holds a $\mathrm{PhD}$ in Economics from the London School of Economics.

Jati Utomo Dwi Hatmoko is a Senior Lecturer in Civil Engineering at the Diponegoro University, Indonesia. He completed his master's and $\mathrm{PhD}$ in construction management from Newcastle University, UK. His research interests include sustainable construction, lean construction, building information modelling, construction supply chain management, risk management and public-private partnership. His work has been published in journals and he has been actively involved in peerreviewing several international journals. His research has been funded by government bodies, such as Indonesia's Ministry of Public Works and Construction Services Development Board and Ministry of Research and Higher Education.

Sholihin As'ad is the Dean of Faculty of Engineering and Lecturer at the Department of Civil Engineering at the Universitas Sebelas Maret (UNS), Indonesia. He received his bachelor's and master's degrees in civil engineering from Institut Teknologi Bandung (ITB), and doctorate degree in civil engineering from Leopold Franzens Universitat Innsbruck, Austria. Prior to his current university career, he was a Civil Engineer at LAPI ITB Engineering Consultant for several infrastructure projects in Batam Island, Indonesia, for six years. He was a PhD External Examiner at several universities, including Curtin University (Australia), Universitas Diponegoro and Universitas Hasanuddin (Indonesia).

Chusu He is a Lecturer of Finance at Coventry University London. She previously worked as a Research Associate, and received her $\mathrm{PhD}$ degree in financial economics (2014-2018) and MSc degree in banking with distinction (2013-2014) from the School of Business and Economics, Loughborough University. She also passed the three levels of the Chartered Financial Analyst exams during 20152017. Her $\mathrm{PhD}$ thesis was in the field of infrastructure and project finance, public procurement and public-private partnerships. She has since been developing new research into financial technology, payments and settlement and supply chain finance.

For instructions on how to order reprints of this article, please visit our website:

www.emeraldgrouppublishing.com/licensing/reprints.htm

Or contact us for further details: permissions@emeraldinsight.com 